\title{
Comparison of a latex agglutination test with other serological tests for the measurement of antibodies to Toxoplasma gondii
}

\author{
RA PAYNE, JM FRANCIS, W KWANTES \\ From the Public Health Laboratory, Swansea, Wales
}

SUMMARY One hundred sera from 49 patients with glandular toxoplasmosis were examined by a latex agglutination test, the dye test, an indirect haemagglutination test, and a double antibody sandwich enzyme linked immunosorbent assay (ELISA) for antitoxoplasma IgM. The results support previous findings that the dye test, indirect haemagglutination test, and latex agglutination test measure different antibodies to Toxoplasma gondii. In early glandular toxoplasmosis, when specific IgM was detected, the titres of both the latex agglutination test and the indirect haemagglutination test were lower than the dye test. Repeat specimens from 11 of the patients showed four cases in which the latex agglutination test titres never exceeded $1 / 256$, whereas both the dye test and the indirect haemagglutination test showed significant titres and specific IgM was detected in every case.

We conclude that the latex agglutination test should not be used as a substitute for the dye test in the serological diagnosis of glandular toxoplasmosis. All sera giving a positive latex agglutination test result should be referred for further tests. A combination of the dye test and double antibody sandwich ELISA gives the most reliable serological diagnosis of early glandular toxoplasmosis.

The Swansea Public Health Laboratory is one of three in England and Wales to which specimens are referred from other laboratories for serological evidence of toxoplasmosis. The tests routinely used are the dye test ${ }^{1}$ and a test for toxoplasma specific IgM antibody. Since 1982 a double antibody sandwich enzyme linked immunosorbent assay (ELISA) has been used for the latter. ${ }^{2}$

In recent years some laboratories have been testing sera by a latex agglutination test (Toxotest-MT, Eiken, Tokyo, Japan) before submitting them to the reference laboratories and many discrepancies between latex agglutination test and dye test titres have been noted. This study shows the results obtained with 100 serum samples from 49 cases of glandular toxoplasmosis tested by a latex agglutination test, the dye test, an indirect haemagglutination test, and double antibody sandwich ELISA.

\section{Material and methods}

\section{LATEX AGGLUTINATION TEST}

The Toxotest MT, an indirect latex agglutination test, was carried out as recommended in the manu-

Accepted for publication 15 August 1984 facturer's instructions. Four kits were purchased, each enabling 50 samples to be tested; all were from the same batch (lot no 37046) and were used before the stated expiry date.

\section{DYE TEST}

The dye tests were performed in flat bottomed microtitre plates and read directly with an inverted microscope. Details of the method are given in PHLS Monograph $13 .^{3}$

\section{INDIRECT HAEMAGGLUTINATION TEST}

The reagents were prepared by the method of Thorburn and Williams ${ }^{4}$ and the test performed as described in PHLS Monograph 13. ${ }^{3}$

DOUBLE ANTIBODY SANDWICH ELISA FOR IgM The method of detecting antitoxoplasma IgM by double antibody sandwich ELISA has been described elsewhere. ${ }^{2}$ The method has been modified in that the conjugate is prepared from human serum with a high dye test titre. Dye test negative human serum is used for the blocking procedure. The results are expressed as test to negative (T:N) ratios where $\mathbf{N}$ is the mean absorbance of six IgM 
Table 1 Results of four serological tests on sera from 49 cases of toxoplasma lymphadenopathy related to time of onset of symptoms

\begin{tabular}{|c|c|c|c|c|c|}
\hline Patient's serum no & Dye test & $\begin{array}{l}\text { Indirect } \\
\text { haemagglutination test }\end{array}$ & $\begin{array}{l}\text { Latex } \\
\text { agglutination test }\end{array}$ & $\begin{array}{l}T: N \text { ratio } \\
\text { ELISA IgM }\end{array}$ & $\begin{array}{l}\text { Time after } \\
\text { onset (mo) }\end{array}$ \\
\hline $\begin{array}{c}1 \mathrm{~A} \\
2 \mathrm{~A} \\
3 \mathrm{~A} \\
4 \mathrm{~A} \\
5 \mathrm{~A} \\
6 \mathrm{~A} \\
7 \mathrm{~A} \\
8 \mathrm{~A} \\
9 \mathrm{~A} \\
10 \mathrm{~A} \\
11 \mathrm{~A} \\
12 \mathrm{~A} \\
13 \mathrm{~A} \\
14 \mathrm{~A} \\
15 \mathrm{~A} \\
16 \mathrm{~A} \\
2 \mathrm{~B} \\
17 \mathrm{~A} \\
18 \mathrm{~A} \\
19 \mathrm{~A} \\
3 \mathrm{~B} \\
20 \mathrm{~A} \\
6 \mathrm{~B} \\
21 \mathrm{~A} \\
22 \mathrm{~A} \\
23 \mathrm{~A} \\
24 \mathrm{~A} \\
25 \mathrm{~A} \\
15 \mathrm{~B} \\
26 \mathrm{~A} \\
27 \mathrm{~A} \\
28 \mathrm{~A} \\
1 \mathrm{~B} \\
29 \mathrm{~A} \\
3 \mathrm{C} \\
30 \mathrm{~A} \\
24 \mathrm{~B} \\
31 \mathrm{~A} \\
32 \mathrm{~A} \\
30 \mathrm{~B} \\
33 \mathrm{~A} \\
34 \mathrm{~A} \\
35 \mathrm{~A} \\
27 \mathrm{~B} \\
23 \mathrm{~B} \\
36 \mathrm{~A} \\
11 \mathrm{~B} \\
22 \mathrm{~B} \\
16 \mathrm{~B} \\
37 \mathrm{~A}\end{array}$ & $\begin{array}{r}16000 \\
4096 \\
4096 \\
32000 \\
2048 \\
512 \\
4096 \\
128 \\
8192 \\
16000 \\
1024 \\
16000 \\
16000 \\
16000 \\
2048 \\
4096 \\
4096 \\
512 \\
4096 \\
32000 \\
8192 \\
256 \\
4096 \\
4096 \\
4096 \\
4096 \\
4096 \\
4096 \\
16000 \\
8192 \\
2048 \\
2048 \\
16000 \\
4096 \\
4096 \\
4096 \\
4096 \\
2048 \\
4096 \\
2048 \\
16000 \\
8192 \\
4096 \\
2048 \\
4096 \\
4096 \\
1024 \\
32000 \\
1024 \\
4096\end{array}$ & $\begin{array}{r}2048 \\
1024 \\
512 \\
2048 \\
512 \\
256 \\
4096 \\
64 \\
256 \\
1024 \\
2048 \\
32000 \\
2048 \\
2048 \\
1024 \\
4096 \\
2048 \\
64 \\
1024 \\
16000 \\
2048 \\
128 \\
2048 \\
2048 \\
2048 \\
1024 \\
1024 \\
2048 \\
4096 \\
16000 \\
1024 \\
1024 \\
4096 \\
4096 \\
1024 \\
1024 \\
4096 \\
512 \\
2048 \\
1024 \\
1024 \\
2048 \\
16000 \\
512 \\
4096 \\
1024 \\
4096 \\
16000 \\
2048 \\
4096\end{array}$ & $\begin{array}{r}1024 \\
512 \\
256 \\
1024 \\
512 \\
128 \\
2048 \\
256 \\
128 \\
1024 \\
256 \\
2048 \\
1024 \\
1024 \\
1024 \\
256 \\
2048 \\
128 \\
256 \\
2048 \\
256 \\
1024 \\
256 \\
1024 \\
1024 \\
1024 \\
512 \\
256 \\
1024 \\
2048 \\
128 \\
64 \\
1024 \\
256 \\
256 \\
128 \\
512 \\
128 \\
128 \\
128 \\
512 \\
512 \\
512 \\
64 \\
512 \\
128 \\
512 \\
4096 \\
128 \\
256\end{array}$ & $\begin{array}{r}13 \\
13 \\
10 \\
9 \\
9 \\
8 \\
7 \\
7 \\
6 \\
5 \\
5 \\
5 \\
5 \\
5 \\
4 \\
3 \\
15 \\
13 \\
11 \\
10 \\
8 \\
8 \\
7 \\
6 \\
6 \\
5 \\
5 \\
5 \\
4 \\
4 \\
3 \\
15 \\
12 \\
7 \\
7 \\
7 \\
6 \\
6 \\
5 \\
5 \\
4 \\
4 \\
4 \\
4 \\
3 \\
3 \\
1 \\
9\end{array}$ & $\begin{array}{l}1 \\
1 \\
1 \\
1 \\
1 \\
1 \\
1 \\
1 \\
1 \\
1 \\
1 \\
1 \\
1 \\
1 \\
1 \\
1 \\
2 \\
2 \\
2 \\
2 \\
2 \\
2 \\
2 \\
2 \\
2 \\
2 \\
2 \\
2 \\
2 \\
2 \\
2 \\
3 \\
3 \\
3 \\
3 \\
3 \\
3 \\
3 \\
3 \\
3 \\
3 \\
3 \\
3 \\
3 \\
3 \\
3 \\
3 \\
3 \\
3 \\
4\end{array}$ \\
\hline
\end{tabular}

negative sera tested at the same dilution as the test sera. A ratio of 2 or more is considered to be a positive result. The toxoplasma national control serum (PHL, St George's Hospital, London) was included as a positive control with each batch of tests. This serum has a dye test titre of $1 / 2048$ $(1000 \mathrm{IU} / \mathrm{ml})$, indirect haemagglutination test titre of 1/1024, and an immunofluorescent IgM antibody titre of $1 / 8$. The double antibody sandwich ELISA consistently gave a T:N ratio of between 4 and 6 .

\section{SPECIMENS}

One hundred sera from 49 patients with glandular toxoplasmosis were selected from specimens submitted to the laboratory for examination. The initial specimen from each patient showed the presence of specific antitoxoplasma IgM. Three or more specimens were sent from 11 of the patients. The interval between the date of collection and the onset of lymphadenopathy was established to within one month in each case.

\section{Results}

The results obtained with the four serological tests and the interval between specimen collection and the onset of lymphadenopathy are shown in Table 1. Although toxoplasma antibody could be detected by the dye test, indirect haemagglutination test, and latex agglutination test in all specimens, the titres 
Table 1-continued

\begin{tabular}{|c|c|c|c|c|c|}
\hline Patient's serum no. & Dye test & $\begin{array}{l}\text { Indirect } \\
\text { haemagglutination test }\end{array}$ & $\begin{array}{l}\text { Latex } \\
\text { agglutination test }\end{array}$ & $\begin{array}{l}\text { T:N ratio } \\
\text { ELISA IgM }\end{array}$ & $\begin{array}{l}\text { Time after } \\
\text { onset (mo) }\end{array}$ \\
\hline $\begin{array}{l}38 \mathrm{~A} \\
39 \mathrm{~A} \\
40 \mathrm{~A} \\
41 \mathrm{~A} \\
42 \mathrm{~A} \\
43 \mathrm{~A} \\
18 \mathrm{~B} \\
44 \mathrm{~A} \\
45 \mathrm{~A} \\
39 \mathrm{~B} \\
8 \mathrm{~B} \\
19 \mathrm{~B} \\
24 \mathrm{C} \\
46 \mathrm{~A} \\
17 \mathrm{~B} \\
9 \mathrm{~B} \\
2 \mathrm{C} \\
28 \mathrm{~B} \\
10 \mathrm{~B} \\
47 \mathrm{~A} \\
45 \mathrm{~B} \\
19 \mathrm{C} \\
30 \mathrm{C} \\
38 \mathrm{~B} \\
28 \mathrm{C} \\
42 \mathrm{~B} \\
10 \mathrm{C} \\
18 \mathrm{C} \\
48 \mathrm{~A} \\
12 \mathrm{~B} \\
6 \mathrm{C} \\
39 \mathrm{C} \\
17 \mathrm{C} \\
26 \mathrm{~B} \\
25 \mathrm{~B} \\
6 \mathrm{D} \\
49 \mathrm{~A} \\
30 \mathrm{D} \\
35 \mathrm{~B} \\
24 \mathrm{D} \\
28 \mathrm{D} \\
43 \mathrm{~B} \\
10 \mathrm{D} \\
13 \mathrm{~B} \\
17 \mathrm{D} \\
14 \mathrm{~B} \\
4 \mathrm{~B} \\
6 \mathrm{E} \\
49 \mathrm{~B} \\
19 \mathrm{D}\end{array}$ & $\begin{array}{r}1024 \\
16000 \\
512 \\
32000 \\
16000 \\
16000 \\
4096 \\
4096 \\
16000 \\
8192 \\
512 \\
32000 \\
2048 \\
16000 \\
4096 \\
4096 \\
4096 \\
2048 \\
8192 \\
8192 \\
8192 \\
16000 \\
2048 \\
1024 \\
2048 \\
4096 \\
2048 \\
2048 \\
8192 \\
2048 \\
4096 \\
1024 \\
2048 \\
8192 \\
1024 \\
4096 \\
8192 \\
1024 \\
4096 \\
128 \\
2048 \\
2048 \\
1024 \\
512 \\
4096 \\
512 \\
1024 \\
2048 \\
2048 \\
1024\end{array}$ & $\begin{array}{r}1024 \\
4096 \\
4096 \\
4096 \\
32000 \\
16000 \\
2048 \\
8192 \\
2048 \\
2048 \\
256 \\
64000 \\
2048 \\
2048 \\
4096 \\
2048 \\
16000 \\
2048 \\
4096 \\
16000 \\
8192 \\
64000 \\
4096 \\
1024 \\
512 \\
64000 \\
2048 \\
2048 \\
64000 \\
4096 \\
8192 \\
1024 \\
2048 \\
64000 \\
8192 \\
4096 \\
64000 \\
2048 \\
32000 \\
1024 \\
512 \\
16000 \\
2048 \\
1024 \\
8192 \\
4096 \\
2048 \\
4096 \\
64000 \\
4096\end{array}$ & $\begin{array}{r}128 \\
512 \\
512 \\
1024 \\
4096 \\
1024 \\
128 \\
1024 \\
512 \\
512 \\
256 \\
8192 \\
128 \\
512 \\
512 \\
256 \\
1024 \\
64 \\
1024 \\
1024 \\
512 \\
8192 \\
256 \\
128 \\
64 \\
2048 \\
512 \\
128 \\
2048 \\
256 \\
512 \\
128 \\
512 \\
2048 \\
512 \\
1024 \\
4096 \\
64 \\
512 \\
64 \\
64 \\
1024 \\
128 \\
64 \\
512 \\
64 \\
256 \\
1024 \\
2048 \\
512 \\
\end{array}$ & $\begin{array}{l}7 \\
5 \\
5 \\
4 \\
4 \\
2 \\
8 \\
6 \\
5 \\
5 \\
5 \\
4 \\
4 \\
3 \\
2 \\
1 \\
9 \\
8 \\
3 \\
2 \\
6 \\
4 \\
4 \\
1 \\
6 \\
4 \\
3 \\
3 \\
2 \\
1 \\
4 \\
4 \\
2 \\
1 \\
1 \\
4 \\
3 \\
2 \\
1 \\
1 \\
3 \\
1 \\
1 \\
1 \\
1 \\
1 \\
1 \\
1 \\
1 \\
\end{array}$ & $\begin{array}{l}4 \\
4 \\
4 \\
4 \\
4 \\
4 \\
5 \\
5 \\
5 \\
5 \\
5 \\
5 \\
5 \\
5 \\
5 \\
5 \\
6 \\
6 \\
6 \\
6 \\
7 \\
7 \\
7 \\
7 \\
8 \\
8 \\
8 \\
8 \\
8 \\
8 \\
9 \\
9 \\
9 \\
9 \\
9 \\
10 \\
10 \\
10 \\
10 \\
10 \\
11 \\
12 \\
12 \\
12 \\
13 \\
13 \\
14 \\
15 \\
16 \\
20\end{array}$ \\
\hline
\end{tabular}

Table 2 Comparison of latex agglutination test and dye test titres of sera from cases of glandular toxoplasmosis

\begin{tabular}{|c|c|c|c|c|c|c|c|c|c|}
\hline \multirow[t]{2}{*}{ Dye test titre } & \multicolumn{8}{|c|}{ Latex agglutination test titre } & \multirow{2}{*}{ Total } \\
\hline & 64 & 128 & 256 & 512 & 1024 & 2048 & 4000 & 8000 & \\
\hline $\begin{array}{r}<512 \\
512 \\
1024 \\
2048 \\
4000 \\
8000 \\
16000 \\
32000 \\
\text { Total }\end{array}$ & $\begin{array}{l}1 \\
2 \\
1 \\
5\end{array}$ & $\begin{array}{l}2 \\
5 \\
5 \\
4 \\
1\end{array}$ & $\begin{array}{l}1 \\
1 \\
2 \\
2 \\
9 \\
1\end{array}$ & $\begin{array}{r}1 \\
3 \\
3 \\
9 \\
3 \\
4 \\
23\end{array}$ & $\begin{array}{r}1 \\
\\
3 \\
5 \\
3 \\
7 \\
2 \\
21\end{array}$ & $\begin{array}{l}1 \\
3 \\
3 \\
1 \\
1 \\
9\end{array}$ & $\begin{array}{l}1 \\
1 \\
1 \\
3\end{array}$ & $\begin{array}{l}1 \\
1 \\
2\end{array}$ & $\begin{array}{r}3 \\
6 \\
11 \\
19 \\
30 \\
12 \\
14 \\
5 \\
100\end{array}$ \\
\hline
\end{tabular}

varied greatly. In specimens taken early in the disease the dye test titres were usually higher than the indirect haemagglutination test titres, whereas specimens taken late in the disease showed higher indirect haemagglutination test titres than dye test titres. Dye test titres were higher than indirect 
Table 3 Comparison of latex agglutination test and indirect haemagglutination test titres of sera from cases of glandular toxoplasmosis

\begin{tabular}{|c|c|c|c|c|c|c|c|c|c|}
\hline \multirow{2}{*}{$\begin{array}{l}\text { Indirect haemagglutination } \\
\text { test titre }\end{array}$} & \multicolumn{8}{|c|}{ Latex agglutination test titre } & \multirow[t]{2}{*}{ Total } \\
\hline & 64 & 128 & 256 & 512 & 1024 & 2048 & 4000 & 8000 & \\
\hline $\begin{array}{r}<512 \\
512 \\
1024 \\
2048 \\
4000 \\
8000 \\
16000 \\
32000 \\
\text { Total }\end{array}$ & $\begin{array}{l}3 \\
3 \\
2 \\
1\end{array}$ & $\begin{array}{l}3 \\
1 \\
7 \\
6\end{array}$ & $\begin{array}{l}2 \\
1 \\
2 \\
6 \\
5\end{array}$ & $\begin{array}{r}1 \\
3 \\
6 \\
7 \\
4 \\
1 \\
1 \\
23\end{array}$ & $\begin{array}{r}1 \\
3 \\
6 \\
6 \\
1 \\
4 \\
\\
21\end{array}$ & $\begin{array}{l}1 \\
1 \\
2 \\
5 \\
9\end{array}$ & $\begin{array}{l}1 \\
2 \\
3\end{array}$ & $\begin{array}{l}2 \\
2\end{array}$ & $\begin{array}{r}6 \\
6 \\
18 \\
27 \\
20 \\
7 \\
6 \\
10 \\
100\end{array}$ \\
\hline
\end{tabular}

Table 4 Results of four serological tests on sequential sera from 11 cases of glandular toxoplasmosis related to time of onset of symptoms

\begin{tabular}{|c|c|c|c|c|c|}
\hline Patient's serum no & Dye test & $\begin{array}{l}\text { Indirect } \\
\text { haemagglutination test }\end{array}$ & $\begin{array}{l}\text { Latex } \\
\text { agglutination test }\end{array}$ & $\begin{array}{l}\text { T:N ratio } \\
\text { ELISA IgM }\end{array}$ & $\begin{array}{l}\text { Time after onset } \\
(\mathrm{mo})\end{array}$ \\
\hline $\begin{array}{r}\mathbf{2 A} \\
\mathbf{B} \\
\mathbf{C}\end{array}$ & $\begin{array}{l}4096 \\
4096 \\
4096\end{array}$ & $\begin{array}{r}1024 \\
2048 \\
16000\end{array}$ & $\begin{array}{r}512 \\
2048 \\
1024\end{array}$ & $\begin{array}{r}13 \\
15 \\
9\end{array}$ & $\begin{array}{l}1 \\
2 \\
6\end{array}$ \\
\hline $\begin{array}{r}\mathbf{3 A} \\
\mathbf{B} \\
\mathbf{C}\end{array}$ & $\begin{array}{l}4096 \\
8192 \\
4096\end{array}$ & $\begin{array}{r}512 \\
2048 \\
1024\end{array}$ & $\begin{array}{l}256 \\
256 \\
256\end{array}$ & $\begin{array}{r}10 \\
8 \\
7\end{array}$ & $\begin{array}{l}1 \\
2 \\
3\end{array}$ \\
\hline $\begin{array}{c}\mathbf{6 A} \\
\mathbf{B} \\
\mathbf{C} \\
\mathbf{D} \\
\mathbf{E}\end{array}$ & $\begin{array}{r}512 \\
4096 \\
4096 \\
4096 \\
2048\end{array}$ & $\begin{array}{r}256 \\
2048 \\
8192 \\
4096 \\
4096\end{array}$ & $\begin{array}{r}128 \\
256 \\
512 \\
1024 \\
1024\end{array}$ & $\begin{array}{l}8 \\
7 \\
4 \\
4 \\
1\end{array}$ & $\begin{array}{r}1 \\
2 \\
9 \\
10 \\
15\end{array}$ \\
\hline $\begin{array}{r}10 \mathrm{~A} \\
\mathbf{B} \\
\mathbf{C} \\
\mathbf{D}\end{array}$ & $\begin{array}{r}16000 \\
8192 \\
2048 \\
1024\end{array}$ & $\begin{array}{l}1024 \\
4096 \\
2048 \\
2048\end{array}$ & $\begin{array}{r}1024 \\
1024 \\
512 \\
128\end{array}$ & $\begin{array}{l}5 \\
3 \\
3 \\
1\end{array}$ & $\begin{array}{r}1 \\
6 \\
8 \\
12\end{array}$ \\
\hline $\begin{array}{r}17 \mathbf{A} \\
\mathbf{B} \\
\mathbf{C} \\
\mathbf{D}\end{array}$ & $\begin{array}{r}512 \\
4096 \\
2048 \\
4096\end{array}$ & $\begin{array}{r}64 \\
4096 \\
2048 \\
8192\end{array}$ & $\begin{array}{l}128 \\
512 \\
512 \\
512\end{array}$ & $\begin{array}{r}13 \\
2 \\
2 \\
1\end{array}$ & $\begin{array}{r}2 \\
5 \\
9 \\
13\end{array}$ \\
\hline $\begin{array}{r}18 \mathbf{A} \\
\mathrm{B} \\
\mathbf{C}\end{array}$ & $\begin{array}{l}4096 \\
4096 \\
2048\end{array}$ & $\begin{array}{l}1024 \\
2048 \\
2048\end{array}$ & $\begin{array}{l}256 \\
128 \\
128\end{array}$ & $\begin{array}{r}11 \\
8 \\
3\end{array}$ & $\begin{array}{l}2 \\
5 \\
8\end{array}$ \\
\hline $\begin{array}{r}19 \mathrm{~A} \\
\mathrm{~B} \\
\mathrm{C} \\
\mathrm{D}\end{array}$ & $\begin{array}{r}32000 \\
32000 \\
16000 \\
1024\end{array}$ & $\begin{array}{r}16000 \\
64000 \\
64000 \\
4096\end{array}$ & $\begin{array}{r}2048 \\
8192 \\
8192 \\
512\end{array}$ & $\begin{array}{r}10 \\
4 \\
4 \\
1\end{array}$ & $\begin{array}{r}2 \\
5 \\
7 \\
20\end{array}$ \\
\hline $\begin{array}{r}24 \mathbf{A} \\
\mathbf{B} \\
\mathbf{C} \\
\mathbf{D}\end{array}$ & $\begin{array}{r}4096 \\
4096 \\
2048 \\
128\end{array}$ & $\begin{array}{l}1024 \\
4096 \\
2048 \\
1024\end{array}$ & $\begin{array}{r}512 \\
512 \\
128 \\
64\end{array}$ & $\begin{array}{l}5 \\
6 \\
4 \\
1\end{array}$ & $\begin{array}{r}2 \\
3 \\
5 \\
10\end{array}$ \\
\hline $\begin{array}{r}28 \mathbf{A} \\
\mathbf{B} \\
\mathbf{C} \\
\mathbf{D}\end{array}$ & $\begin{array}{l}2048 \\
2048 \\
2048 \\
2048\end{array}$ & $\begin{array}{r}1024 \\
2048 \\
512 \\
512\end{array}$ & $\begin{array}{l}64 \\
64 \\
64 \\
64\end{array}$ & $\begin{array}{r}15 \\
8 \\
6 \\
3\end{array}$ & $\begin{array}{r}3 \\
6 \\
8 \\
11\end{array}$ \\
\hline $\begin{array}{r}30 \mathbf{A} \\
\mathbf{B} \\
\mathbf{C} \\
\mathbf{D}\end{array}$ & $\begin{array}{l}4096 \\
2048 \\
2048 \\
1024\end{array}$ & $\begin{array}{l}1024 \\
1024 \\
4096 \\
2048\end{array}$ & $\begin{array}{r}128 \\
128 \\
256 \\
64\end{array}$ & $\begin{array}{l}7 \\
5 \\
4 \\
2\end{array}$ & $\begin{array}{r}3 \\
3 \\
7 \\
10\end{array}$ \\
\hline $\begin{array}{r}39 \mathbf{A} \\
\mathbf{B} \\
\mathbf{C}\end{array}$ & $\begin{array}{r}16000 \\
8192 \\
1024\end{array}$ & $\begin{array}{l}4096 \\
2048 \\
1024\end{array}$ & $\begin{array}{l}512 \\
512 \\
128\end{array}$ & $\begin{array}{l}5 \\
5 \\
4\end{array}$ & $\begin{array}{l}4 \\
5 \\
9\end{array}$ \\
\hline
\end{tabular}


haemagglutination test titres, with 38 of 49 sera taken during the first 3 months after the onset of lymphadenopathy and with nine of 21 sera taken 4 to 6 months after onset. Only two of $\mathbf{3 0}$ sera taken more than 6 months after onset gave dye test titres higher than indirect haemagglutination test titres. This confirms the results of Karim and Ludlam. ${ }^{5}$ There was no such correlation between the latex agglutination test and dye test, or latex agglutination test and indirect haemagglutination test; high and low latex agglutination test titres occurred both early and late in the disease. Antitoxoplasma IgM antibody could be detected by double antibody sandwich ELISA in most cases for about nine months after the onset of lymphadenopathy with higher concentrations occurring early in the disease (Table 1).

Table 2 compares latex agglutination test with dye test results and Table 3 compares latex agglutination test with indirect haemagglutination test results. Only $33 \%$ of the sera gave latex agglutination test titres within a fourfold dilution of the dye test and $42 \%$ within fourfold of the indirect haemagglutination test.

Three or more sera were obtained from 11 of the patients and the results of the tests are shown in Table 4. In four cases the latex agglutination test titre never exceeded $1 / 256$, whereas both the dye test and indirect haemagglutination test showed much higher titres and specific antitoxoplasma IgM was detected in every case. In one case (patient 28) four sera collected over an 8 month period gave constant latex agglutination test titres of $1 / 64$, whereas both the dye test and indirect haemagglutination test titres reached $1 / 2048$ and specific antitoxoplasma IgM was detected in each of the four specimens.

\section{Discussion}

The sera examined were from a selected group of patients with glandular toxoplasmosis and this study was not designed to determine whether the latex agglutination test could be used to screen those sera containing toxoplasma antibody from negative sera. Other workers have found closer agreement between quantitative estimations with the latex agglutination test, dye test, and indirect haemagglutination test than those reported here. Balfour et al $^{6}$ found $78 \%$ of titres within a-fourfold dilution with 339 sera titrated in latex agglutination test and dye test. Tsubota et al compared the results obtained by the latex agglutination test and indirect haemagglutination test and reported a $90.7 \%$ agreement, and high agreement was shown by Kobayashi et $\mathrm{l}^{\mathbf{8}}$ between the latex agglutination test and indirect haemagglutination test and also between the latex agglutination test and dye test. The sera examined by these workers were not related to clinical findings or the onset of illness and the differences in quantitative estimations reported here may therefore be due to the selection of specimens examined. Of the 100 specimens examined, $70 \%$ were collected within 6 months of onset of lymphadenopathy and $82 \%$ contained toxoplasma specific IgM antibody. Balfour et al $^{6}$ did conclude, however, that the pattern of antigenic determinants to which antibody concentrations are measured are different in these three test systems and the results reported here support their findings.

Our conclusions from this study are as follows. Firstly, the latex agglutination test should not be used as a substitute for the dye test in the serological diagnosis of glandular toxoplasmosis because of the variability in the antibody concentrations detected. Secondly, if the latex agglutination test is used as a screening test for glandular toxoplasmosis all sera giving a positive result, whatever the titre, should be sent to a reference laboratory for further studies. Thirdly, early glandular toxoplasmosis may be most reliably diagnosed serologically by a combination of the dye test and a test which detects specific antitoxoplasma IgM antibody. The double antibody sandwich ELISA is a most suitable test for the latter as it is sensitive, specific, and reproducible.

\section{References}

' Sabin A, Feldman HA. Dyes as microchemical indicators of a new immunity phenomenom affecting a protozoan parasite (Toxoplasma). Science 1948; 108:660-3.

2 Payne RA, Isaac M, Francis JM. Enzyme-linked immunosorbent assay (ELISA) using antibody class capture for the detection of anti-toxoplasma IgM. J Clin Pathol 1982;35:892-6.

${ }^{3}$ Fleck DG, Kwantes W. The laboratory diagnosis of toxoplasmosis. Public Health Laboratory Service Monograph 13. London: HMSO, 1980.

4 Thorburn H, Williams H. A stable haemagglutinating antigen for detecting toxoplasma antibodies. J Clin Pathol 1972;25:7627.

${ }^{5}$ Karim KA, Ludlam GB. The relationship and significance of antibody titres as determined by various serological methods in glandular and ocular toxoplasmosis. J Clin Pathol 1975;28:42-9.

- Balfour AH, Fleck DG, Hughes HPA, Sharp D. Comparative study of three tests (dye test, indirect haemagglutination test, latex agglutination test) for the detection of antibodies to Toxoplasma gondii in human sera. J Clin Pathol 1982;35:228-32.

' Tsubota N, Hiroaka H, Sawada Y, Watanaba T, Ohshima S. Studies on latex agglutination test for toxoplasmosis. (2) Evaluation of the microtitre test as a serologic test for Toxoplasmosis in man. Jpn J Parasitol 1977;26:286-90.

- Kobayashi A, Hirai N, Suzuki Y, Nishikawa H, Watanabe N. Evaluation of a commercial toxoplasma latex agglutination test. Jpn J Parasitol 1977; 26: 175-80.

Requests for reprints to: Mr RA Payne, Public Health Laboratory, Cockett Road, Swansea, Wales. 